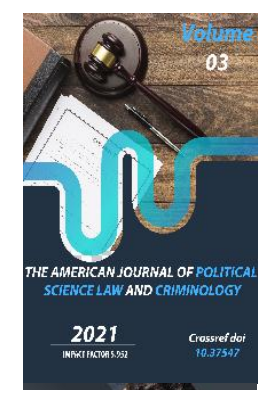

\title{
The Role Of The Institution Of Judicial Review In Ensuring The Independence Of The Judiciary
}

Dilshod Aripov Urinboevich

Ph.D., Associate Professor, Adviser To Director Of The Supreme School Of Judges, Uzbekistan

Journal Website:

http://theamericanjour

nals.com/index.php/taj

pslc

Copyright: Original

content from this work

may be used under the

terms of the creative

commons attributes

4.0 licence.

\section{ABSTRACT}

This article discusses the role of the institute of judicial review in ensuring the independence of the judiciary; its importance in ensuring the rights and freedoms of citizens; its differences from fair trial; its types and forms of implementation; its subjects and objects; its purpose and content; its characteristics of execution through legal and disciplinary norms; its functions in law enforcement, regulation, organizational maintenance, education; as well as its prospects in strengthening the independence of the judiciary from other branches of government.

\section{KEYWORDS}

Review, control, judicial review, constitutional review, general judicial review, special judicial review, forms of judicial review, fair trial, substantial and procedural law.

\section{INTRODUCTION}

The introduction of the institute of judicial review in the Republic of Uzbekistan is one of the main directions of judicial and legal reforms. In the doctrine of law, judicial review is now considered as one of the functions of the judiciary, which is recognized not only as a procedural guarantee of the rights and freedoms of citizens, but also as a means of establishing the rule of law in a society.
Therefore, nowadays, the perception that the judiciary should administer only fair trial has changed, leading to the need for judicial review in order to achieve full justice. This, in turn, serves to ensure the rule of law in practice by exerting its influence on ensuring the supremacy of law in all spheres of public life. As a result, this promotes the system in which state bodies, their officials and citizens 
are obliged to comply with the law; where violations of the law are prevented or eliminated; when citizens are protected by courts both during court proceedings and in the post-trial stages.

Different opinions are put forward on the difference between the concepts of "review" and "control" among scientists, taking into account the subordination of the object of control to the subject of control as the main criterion. In particular, H. Odilkariev, B. Kasimov, E. Hodzhiev and T. Hodzhiev explain the concept of review "as a type of management activity carried out by specially authorized state bodies in order to ensure the rule of law in the activities of objects that are not subordinated to them". ${ }^{1}$

D. Mirazov, on the other hand, is of the opinion that the concept of "judicial control" is more rational to be used in order to define not the process when the courts on criminal cases take control over actions and decisions of the investigative bodies in pre-trial period, but the process of oversight over the legality of those actions and decisions. ${ }^{2}$

According to the Uzbek dictionary, the word "control" is derived from the word "controlecontre role", which means to check, to supervise, while the word "review" is

${ }^{1}$ Odilqoriev H.T., Qosimov B.E , Administrative law. Textbook. (2010) p. 448. Khojiev E., Khojiev T., Administrative law. Textbook. (2008) p.317318.

${ }^{2}$ Mirazov D.M. Control and supervision in the preliminary investigation: Historical, organizational and procedural aspects: Monograph. (Academy of the Ministry of Internal Affairs of the Republic of Uzbekistan, 2015) p. 72. explained as to manage, to constantly monitor actions of some parties, to check. ${ }^{3}$

According to the Uzbek legal encyclopedia, "review" is one of the forms of activity of state bodies aimed at ensuring the rule of law. ${ }^{4}$

In our opinion, in both cases, control and review are aimed at the same goal, and it is not expedient to divide it into types according to their objects. In addition, since the word "control" is not derived from the Uzbek language, it is not appropriate to include it in legal terminology only on a formal basis. Therefore, instead of subordinating the objects of review in order to define the concept, it is more rational to pay attention into the forms and powers of control conferred on it by the law in order to specify general and special types of judicial review. In particular, due to the fact that the procedural mechanism of judicial review of preliminary investigative actions and the review of decisions of lower courts by a higher court is specified in the law, it is rational to classify them collectively as a special judicial review, whereas, the supervision over the execution of decisions of the Plenum of the Supreme Court by the courts, supervision over the execution of other court orders, supervision by regional courts over activities of interdistrict, district courts can be generalized as a general judicial review.

From the point of view of the division of judicial review into general and special types, its forms can vary from the execution of a fair

\footnotetext{
${ }^{3}$ Annotated dictionary of the Uzbek language: "National encyclopedia of Uzbekistan" (State Scientific Publishing House, 2006).

4 Legal Encyclopedia of Uzbekistan. (Adolat, 2010) p. 328.
} 
trial to application of administrative mechanisms. In particular, general judicial review means the control of higher courts over the activities of subordinate courts not related to the administration of justice (institutional review), and special judicial review means control over certain activities in accordance with the procedure established by law (procedural rules). This can be summarized as both judicial review and execution of a fair trial are performed in administrative forms. Thus, while the general court review takes the form of administrative measures only within the powers established by the substantial law, the special judicial review is exercised in the manner prescribed by the procedural law.

This is supported by L. Savyuk and N. Kolokolov, who confirmed that the judiciary functions take the form not only of a fair trial, but also of the constitutional review over the legality of normative documents; judicial review over the legality and validity of decisions, as well as, action of the bodies carrying out operational search, inquiry and preliminary investigations; guarantee of enforcement of judicial decisions; interpretation of laws based on judicial practice; formation of judicial corpus; assistance to judicial society; overview over the legality of decisions of local representative and executive bodies. ${ }^{5}$

Thus, judicial review differs from administration of a fair trial in the following ways:

5 Savyuk L.K. Law enforcement agencies, (2007) p. 86-88; Kolokolov N.A. Judicial control at the stage of preliminary investigation (2004) p. 16-27.
Judicial review is performed not always in a procedural form;

Fair trial is one of the forms of judicial review; While fair trial is administered on the basis of application and complaint of the parties, Judicial review is initiated by the competent courts;

Judicial review shall be exercised on the basis of the rules of substantive law, while fair trial shall be exercised on the basis of the rules of procedural law.

The legal basis of judicial review is provided by substantive and procedural laws, through which the courts may protect the rights and freedoms of citizens during the process of administration of justice and any subsequent stages. In particular, the administrative courts should consider the obligations of administrative bodies and their officials to ensure the rights and freedoms of citizens by considering complaints about illegal actions (inaction) and decisions of officials.

It should be noted that the judicial review over the legality of decisions and actions (inactions) of state bodies and public organizations deserves particular attention, as, unlike other supervisory bodies, courts are independent and impartial, and do not serve for the interest of other parties.

According to M. Umarova, judicial review is a specific form of administration of justice and can never be considered as a separate function of the judiciary. Since the essence of events are revealed by the particular features of it, those of judicial review are: independent action of the court in the administration of justice; execution by independent judicial bodies (judges); implementation in a certain 
prescribed procedural form; fulfillment of two main tasks by judicial review: protection of the rights and interests of legal entities and individuals, and taking measures to ensure the rule of law in decision-making by the authorities. $^{6}$

In our opinion, this view is also controversial, because the judicial review is a broader concept if compared to the concept of a fair trial. It comprises overall oversight over execution of a fair trial and general review performed by administrative mechanisms. As evidence, Articles 13, 26, 30, 34, and 74 of the Law “On Courts" provide for institutional review by the courts, and Articles 24-26 provide for special review the administration of a fair trial. ${ }^{7}$

Simultaneously, it is important to focus on the powers of the Constitutional Court to exercise review over the legislation. In accordance with the Law "On the Constitutional Court of the Republic of Uzbekistan", Constitutional Court exercises special control over non-negative impact of normative legal acts on the constitutional rights and freedoms of citizens by determining the legality and constitutionality of the laws of the Republic of Uzbekistan and resolutions of the chambers of the Oliy Majlis of the Republic of Uzbekistan, decrees, resolutions and orders of the President of the Republic of Uzbekistan, decisions of the government, local state authorities, interstate contractual and other obligations of the Republic of Uzbekistan.

Thus, judicial review performs other functions as well, such as: checking the compliance of

$6 \quad$ Umarova M.A. The mechanism of judicial control: a general theoretical study. Dissertation at KYHN. (2018).

${ }^{7}$ https://lex.uz/docs/68532 the activities of state bodies and their officials with the law and the tasks assigned to them; protection of the constitutional rights and freedoms of citizens by identifying and eliminating violations and taking measures against the perpetrators; maintenance of checks and balances between state powers, along with insurance of the rule of law and justice in a society.

Taking into account all abovementioned, judicial review is a form of exercising judicial power, aimed at protecting the constitutional rights and freedoms of citizens and legal entities in accordance with the law in pre-trial, trial and post-trial stages of hearings, along with restoration of violated rights and insurance of the legality of the activities of public authorities.

According to the objects of judicial review, it can be divided into internal and external types. Internal judicial review means the review of the legality of decisions of civil, criminal, administrative and economic courts by higher courts, and external judicial review refers to the review of the legality of decisions of other bodies of courts and the actions of their officials. This results in expansion of the powers of judiciary in the field of modern law, making it a separate body not only for the administration of justice, but also for judicial review.

In our opinion, depending on the purpose of implementation, general judicial review can be performed in the form of institutional review, while, special one is exercised by way of constitutional, criminal, administrative, civil and economic judicial activity. Here, general review has preventive role, while, special review has role of restoration of violated 
rights and insurance of compliance with the law.

The content of judicial control is comprised of following activities: monitoring the activities of facilities within its competence, which are elements of state control; obtaining and analyzing the accuracy of information about the performance of activities by state bodies; identifying causes and conditions of violations of law; taking measures to prevent negative consequences, damage, accidents, inappropriate actions and expenses by state bodies; keeping records of the offenses committed, determining their causes and circumstances; identifying the wrongdoers bringing them before justice.

The content of judicial control consists of the following components:

a) Normative-legal sources on which the formation and implementation of judicial review is based.

The legal basis for judicial review can be divided into two groups: the first is general legislation (the Constitution, the Law on Courts, etc.), and the second is the legislation (procedural codes, Laws of the Republic of Uzbekistan "On the Constitutional Court of the Republic of Uzbekistan", “On Bankruptcy", "On Administrative Procedures", etc.) that directly regulates certain areas of judicial review;

b) Legal basis on which the subject exercising judicial review and their powers are established. Judicial review is exercised only by the chairmen of courts, judges and judicial staff, and their powers are enshrined in substantive and procedural law; c) Legal means, methods and forms implemented in the process of exercising judicial review.

d) It is the normative nature of legal instruments that undermine the legitimacy of judicial review. It includes legal norms providing for the administration of justice, the review of court decisions, the review and analysis of the activities of the courts, and the application of legal sanctions;

e) Organizational and legal basis for the implementation of judicial review and its effective functioning. They include measures, plans, roadmaps, instructions, guidelines for the correct and effective organization of court proceedings and administrative control.

Judicial review is based not only on legal but also on ethical principles. In particular, this is reflected in the observance of the rules of ethics and internal rules of the courts by judges. For example, in accordance with Article 19 of the Code of ethical conduct of judges of the Republic of Uzbekistan, the Judicial Inspectorate and the relevant judicial qualification boards shall monitor the observance of the provisions of this Code. The Judicial Inspectorate shall submit proposals to the Supreme judicial council to take appropriate measures against a judge, who has violated the provisions of this Code.

In addition, judicial review is not limited with review of only legal document, but also the legality of other documents that, normally, do not have such a nature. In particular, criminal courts review the legality of decisions of inquiry officers, investigators, prosecutors, administrative courts, government officials, and civil and economic courts of all legal entities except government agencies. 
Thus, based on the goals and objectives of judicial review, it can be concluded that it performs such functions as law enforcement, regulation, organizational support, as well as education.

When talking about the specifics of judicial review, it is necessary to focus on the ways how it is performed. There are several ways of judicial review, depending on the purpose, subject, scope of the supervisory function, the effective and complete resolution of the issue:

1) Preliminary (permissive) review (consideration of petitions for the use of the Habeas Corps, allowing the inquiry officers and investigators to conduct procedural and expeditious actions restricting the constitutional rights and freedoms of citizens).

2) Control over the judicial process (identification of violations identified during the trial, making private rulings on the results).

3) Judicial review over the process of consideration and resolution of appeals against decisions or actions (inactions) of state bodies and their officials affecting the constitutional rights and freedoms of citizens.

From the point of view of subjects empowered with judicial review functions, it is solely judiciary, which, can be divided into the Constitutional Court, courts of general jurisdiction and administrative courts. Following this, the courts exercising judicial review can be divided into republican (Constitutional Court, Supreme Court) and lower (regional, district) courts, depending on the jurisdiction of the case. From this point of view, M. Umarova distinguishes between the types of judicial review: constitutional judicial review; review of pre-trial process of criminal proceedings; general and arbitration courts` review over civil, administrative and arbitration proceedings. ${ }^{8}$

From the point of view of the objects of judicial review, these can be divided into: control exercised by the courts of higher instance over the legality of decisions of the courts of lower instances; control over the activities of inquiry and preliminary investigation bodies; oversight over the execution of judicial decisions; control over the constitutionality of normative legal acts adopted by public authorities; supervision over the legality of the activities of executive bodies; institutional review of legality of the courts`activities.

According to the above, the following conclusions can be made:

(a) The independence of judiciary is ensured not only by the process of administration of a fair trial by judiciary, but also by the exercise of a special review functions, which demonstrate distinct power of judiciary in the administration of justice in a society. This is because the effectiveness of the judiciary depends not on the volume of cases decided by them, but on the enforceability of those decisions; the observance of human rights and freedoms, as well as the insurance of the rule of law by other branches of state power. Achieving this goal without judicial review is an impossible task. Therefore, the need for judicial review is social in nature, and its necessity is determined by: a) ensuring the independence of judiciary through self-

\footnotetext{
8 Umarova M.A. Mexanizm sudebnogo kontrolya: obshchetereticheskoe issedovanie. Dissertatsiya na KYUN (2018).
} 
control of the courts; (b) ensuring that the constitutional rights and freedoms of citizens and legal entities are protected by impartial courts; c) guaranteeing the rule of law and justice in a society; (d) maintaining checks and balances between authorities; e) coercion of citizens to obey the law and to respect the rights and freedoms of each other.

(b) The main purpose of judicial review is to prevent violations of rights and freedoms of citizens and legal entities, to restore the violated rights, to ensure the right of every person to a fair trial, and to uphold the rule of law in a society.

(c) In order to ensure the effectiveness of judicial review, it is necessary to improve the existing legislation on order to eliminate inconsistencies and gaps. In particular, it is necessary to development the concept of "judicial review", followed by working on the legislation governing this activity, by taking into account the specific characteristics of the subject and objects in the process of its implementation, and forming the single legal framework for the implementation of judicial review.

(d) Based on the experience of foreign states, it is recommended to extend the power of Constitutional Court of reviewing the legality and constitutionality of not only adopted normative and legal acts, but also those, which are expected to be adopted.
2. Mirazov D.M. Control and supervision in the preliminary investigation: Historical, organizational and procedural aspects: Monograph. (Academy of the Ministry of Internal Affairs of the Republic of Uzbekistan, 2015) p. 72.

3. Annotated dictionary of the Uzbek language: "National encyclopedia of Uzbekistan" (State Scientific Publishing House, 2006).

4. Legal Encyclopedia of Uzbekistan. (Adolat, 2010) p. 328.

5. Savyuk L.K. Law enforcement agencies, (2007) p. 86-88; Kolokolov N.A. Judicial control at the stage of preliminary investigation (2004) p. 16-27.

6. Umarova M.A. The mechanism of judicial control: a general theoretical study. Dissertation at KYHN. (2018).

7. https://lex.uz/docs/68532.

8. Umarova M.A. Mexanizm sudebnogo kontrolya: obshchetereticheskoe issedovanie. Dissertatsiya na KYUN (2018).

\section{REFERENCES}

1. Odilqoriev H.T., Qosimov B.E, Administrative law. Textbook. (2010) p. 448. Khojiev E., Khojiev T., Administrative law. Textbook. (2008) p.317-318. 